\title{
A REGULAMENTAÇÃO DO CONTRATO DE TRABALHO DOS EMPREGADOS DO COMÉRCIO NOS CÓDIGOS MERCANTIS
}

Razões da inserção de normas de direito do trabalho no código comercial de 1850 e inadmissibilidade de sua inclusão no futuro código comercial brasileiro.

\section{Aderbal Freire}

Catedrático da Faculdade de Direito e da Faculdade de Ciências Econômicas do Ceará.

I

PROCESSO DE ELABORAC̃̃O

DO CÓDIGO COMERCIAL DE 1850

Não obstante o concenso geral de que, desde a abertura dos portos brasileiros ao comércio com as nações estrangeiras, em 1808 , se fazia imperiosa a necessidade de uma legislação comercial, codificada para o Brasil, o trabalho de elaboração do Código Comercial, que sòmente em 1833 teve início, estendeu-se por quase dois decênios.

Quando, ainda antes da proclamação da nossa independência, se cogitou, pela primeira vez, de dar ao Brasil um código do comércio, coube ao mais antigo e, sem dúvida, um dos mais notáveis dos nossos comercialistas, José da Silva Lisbôa, visconde de Cayrú, o magno encargo. Essa primeira tentativa, infelizmente, não teve curso, "por fatos que não se podem ter em conta daquele a quem fôra confiada a hercúlea tarefa e que para ela estava indicado por unânime voto" (1).

(1) ALFREDO RUSSEL - Oonferência pronunciada em dez. de 1936, no Ins. tituto da Ordem dos Advogados Brasileiros sôbre a reforma do Código Comercial bra- 
Declarada a nossa independência política, continuamos, por fôrça da lei de 20 de outubro de 1823, a reger-nos, em matéria comercial, pela legislação da antiga metrópole e, subsidiàriamente, pela das demais naçốes civilizadas.

Três códigos eram considerados estatutos padrões, quando tiveram início, no paîs, os trabalhos do nosso atual código mercantil: o Código francês de 1807, o mais antigo de todos e modêlo de quase todos os que the seguiram, o Código espanhol de 1829, que, no dizer do. VISCONDE DE CAYRÚ e do clássico PARDESSUS, era o mais amplo, mais explícito e mais ponderado dos três, e o português de 1833 .

Deve-se à Regência permanente, de que era, então, Ministro da Justiça o cons. Aureliano Coutinho, depois visconde de Sepetiba, iniciativa que culminou com a promulgação do código ainda hoje vigente. Designada, em 1833, uma comissão de quatro negociantes para, sob a presidência do cons. José Clemente Pereira, homem notável por seu talento e virtudes e jurisconsulto de pêso, no jul gamento de ALFREDO RUSSELL e CESAR TRIPOLI $\left({ }^{2}\right)$, - elaborar um projeto de código, desobrigou-se ela de sua missão no ano de 1834, adotando, na feitura da obra que lhe fôra confiada, o duplo critério de calcá-la sôbre os princípios então consagrados nas legislações e nos usos e costumes das nações do novo e do velho mundo e, ao mesmo tempo, adequá-las às condições específicas do país e do seu povo.

Remetido à Câmara êsse projeto, inspirado nos modelos francês, espanhol e português, especialmente no segundo, foi êle submetido ao estudo de uma comissão especial composta de nove membros, tendo como relator o deputado piauiense Francisco de Sousa Martins, comissão essa que o aprovou por unanimidade. Iniciados os debates em 20 de junho de 1834, na Câmara dos Deputados, decidiu-se, na sessão de 23 do mesmo mês, por indicação do deputado Paula Araujo, submetê-lo a novo estudo por uma comissão conjunta de seradores e deputados $\left({ }^{3}\right)$.

Sòmente oito anos depois, essa comissão mista fêz presente ao Parlamento o resultado dos seus estudos, para os quais havia recebido valiosas contribuições, merecendo, entre elas, destaque especial o "Projeto de emendas", apresentado em 1836 por uma comissão de negociantes da Côrte. Levado o projeto, com as emendas recebidas, novamente à discussão na Câmara dos Deputados, em 22 de janeiro de 1845, foi o mesmo mais uma vez submetido à

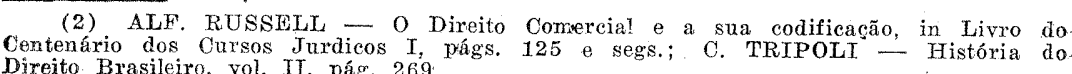
(3) Anais do Parramento Brasileiro, coligidos por Jorge João Dodsworth - Ses- apreciação de uma comissão especial. Essa embora o considerasse "suscetível de alguma perfeição", opinou por sua adoção imediata, pois, no seu entender, cada dia se tornava "mais imperiosa a necesidade de dar ao país um sistema de legislação comercial, para evitar a decadência e a ruína do nosso comércio", que lutava com a incerteza das regras que regiam as questões mecantís, decididas até então "pelo arbítrio dos julgadores e mediante pracessos impróprios e ineficazes" $\left({ }^{4}\right)$.

Pôsto em discussão o projeto com o parecer da comissão, foram ambos, depois de rápidos debates, pràticamente os únicos que o nosso Código suscitou na Câmara baixa, aprovados em globo, em 3 de junho de 1845, sem novas alterações, para evitar o que, de ordinário, ocorre nas assembléias, onde, como afirmou um deputado, citando THIERS, "espíritos medíocres rodeiam um trabalho bem coordenado, fruto de uma profunda experiência, emendam-no, mudam aqui e ali algumas disposições e assim tal barulho armam, que um todo bem ligado e coordenado transformam em um todo informe e incoerente, sem relação com o sistema de legislação e com os fatos reais" $\left({ }^{5}\right)$.

Embora o pensamento dominante fôsse êsse de que os corpos legislativos não são, por sua natureza, os órgãos apropriados para a feitura dos códigos, cabendo-lhes apenas aceitar ou recusar a obra dos técnicos, o Senado do Império houve por bem fazer passar o projeto aprovado na Câmara pelo crivo de longas e severas discussões, em duas sessões legislativas, do que resultou a adoção de numerosas emendas, aprovadas tôdas elas, em 6 de março de 1850, na Câmara dos Deputados, pelo mesmo critério aclamativo, embora com o protesto de alguns membros daquela casa legislativa, entre os quais, o deputado paràense Bernardo de Souza Franco, antigo Ministro do Império e mais tarde visconde de Sousa Franco, que se insurgiu denodadamente contra a aprovação, sem debates, das referidas emendas $\left({ }^{6}\right)$.

Aprovada a sua redação final em 22 de março daquele ano, foi êle sancionado em 2 de maio e promulgado em 25 de junho, por lei que tomou o número 556 e entrou em vigor seis meses após a sua publicação.

Foi assim que se deu ao país uma das leis que, no dizer de SILVA LISBOA, é "das mais debatidas e esmerilhadas do nosso corpo de legislação" e que, "posta èm confronto com legislações similares, não tem de que enrubescer". A respeito dela, aquêle grande comer-

(4) Anais do Parlamento Brasileiro,
egunda sessão de 1845 , tomo $T$,áa. 681 .

(5) Anais cits. tomo II, pag. 24

Pes 
cialista, que só agora vai recebendo a justa consagração de sábio $\left({ }^{7}\right)$, ainda acrescenta, no seu vetusto "Princípios de Direito Mercantil a Leis da Marinha": "Conquanto a jurisprudência comercial e marítima se possa chamar cosmopolita e a tal ponto que o que se legislasse para um país poder-se-ia aplicar integralmente em qualquer outro, o Código que elaboramos tem o característico de, aceitando e admitindo os princípios gerais e uniformes dessa legislação peculiar, consagrar com êles as práticas e usos de há muito em voga em nossas praças e que uma boa razão sancionava e reclamava a continuação. Há pois uma legislação firmada com o cunho brasileiro, revelando, entre outros dotes, no espírito e na redação, o laBor e coloridos pátrios" $\left.{ }^{8}\right)$.

Maior elogio não se lhe poderia dispensar do que o dizer-se que, por todo um século, vem êle regendo, sem desdouro, relaçôes jurídicas que se processam num campo de atividades, com o comércio susceptível às mais variadas mutuações e, muito especialmente, sujeito às modificações que os progressos técnicos imprimem às sociedades ,os quais, é bem ressaltar, durante êsse século de sua vigênucia foram mais intensos e conturbadores do que em qualquer outra fase da história da humanidade ( ${ }^{8 a}$ ).

$\mathrm{Na}$ opinião de CARVALHO DE MENDONÇA, revela um adiantamento notável sôbre os que lhe serviram de modêlo, tendo sido .o primeiro trabalho original dêsse gênero que apareceu na América, pois os de Haití e o da Bolívia, promulgados, respectivamente, em 1826 e 1834, não passavam de cópias servis do Código francês, o primeiro, e do espanhol, o segundo.

Mas onde, a nosso ver, êle mais se alteia e se faz credor da admiração de qualquer jurista que o analise através de um confronto entre a mentalidade dominante na época da sua formação e as concepções jurídicas atuais, é com relação às normas de cunho social contidas no seu contexto e que constituem um notável e surpreendente avanço legislativo, uma vez que os autores daquele código, como que num prenúncio às modernas concepções jurídicas-sociais, se anteciparam em várias dezenas de anos ao atual direito do trabalho, de que são,dessa forma, legítimos precursores, juntamente com o legislador ibérico que, sob os auspícios de Fernando VII, deu à Espanha o Código de 1829.

(7) A. RUSSEL - Conferência cit (8) VISCONDE DE CAYRÚ - Princípios de Dir. Mercantil e Leis de Ma. rinha, 1874, vol. I, pág. DCXIVIIII.

(8-a) Essa assertiva não importa em negax as profundas mutilaçóes que o nosso falêncià, aos títulos de crédito e a alguns tipos de sociedades mercantis. Cumpre, en. tretanto, notar que, quanto aos mais, ainda prevalecem, em suas linhas gerais, as di
E' êsse aspecto do Código Comercial brasileiro que, mais de perto, interessa ao presente trabalho e que, para sua melhor compreensão, exige se examine, preliminarmente, qual o desenvolvimento alcançado, até a época de sua feitura, pelas idéias que deram origem ao moderno direito social.

O DIREITO DO TRABALHO NA ÉPOCA DA PREPARACT̃O DO NOSSO CÓDIGO COMERCIAL

O século XVIII expirou sob o signo de dois acontecimentos de magna importância, fadados ambos a provocar as mais profundas transformações associais já observadas na história da civilização. O primeiro dêles, no terreno político, a Revolução Francesa de 1789 , representou o triunfo da filosofia individualista e dos pressupostos liberais de que resultou a extinção do regime das corporações e a implantacão de um sistema jurídico em que predominava o princípio da liberdade de contrato, como conseqüuência da soberania da vontade individual. O segundo, no campo da ciência, ponto de partida vapor, acontecimento, para MORIN, "plus lourd de conséquence que la Revolution politique de $1789^{\prime \prime}\left({ }^{9}\right)$, que, no pensar de BERG SON, servirá para definir uma idade e do qual se falará mais tarde como hoje nós falamos do bronze e da pedra lascada $\left({ }^{10}\right)$. Já hoje, decorridas quase duas centúrias dessa dupla revolução, é possível afirmar com segurança que êsses dois acontecimentos, embora simultâneos na história da humanidade, não se compadecem, pois - antagonismo entre a revolução das idéias, oriunda do primeiro, e a revolução dos fatos, que resultou do segundo, cedo se revelou. E nesse grave entrechoque dos fatos com as idéias, só estas teríam de ceder terreno, para conformar-se à realidade, pois à marcha inexorável dos acontecimentos não seria possível opor barreira.

As grandes concentrações industriais e comerciais, criadas pelo novo regime econômico, em pouco tempo puseram em destaque essa incompatibilidade entre a realidade dos fatos e o sistema jurídivo vigente. $O$ domínio das fôrças naturais pelos novos processos técnicos exigia o esfôrço coletivo e conjugado de numerosas "equi"es" de trabalhadores e, como essas "equipes" estão sempre em funcão de um equipamento, "le maître de l'équipement risque de devenir le maître de l'équipe", observa SAVATIER (11).

(9) GASTON MORIN - La révolte du droit contre le code, pág. 15

(10) BERGSON L'evolution créatrice, pág. 151. d'anjourd'hui, pag. 13.

$8-$ R. D. $-3 .^{\circ}$ Vol 
Dentro de pouco tempo se havia chegado a uma situação de plorável, sob certos aspectos pior do que a escravatura, porque, aos escravos, o senhor, pelo menos, curava de sua conservação, receoso do prejuízo econômico que resultaria de sua morte, enquanto a vida dos trabalhadores nada representava para os chefes das indústrias.

A decantada igualdade, pregada pelos teóricos liberais e individualistas, constituiu-se um mito e a justiça, que se pretendeu alcançar, através de relações contratuais travadas num clima de antonomia e liberdade, degenerou em iniqüidade.

A constatação gradativa dessas verdades provocou, aos poucos, o nascimento de um anseio de justiça social, exigindo que o Estado se colocasse ao lado do fraco na luta tremendamente desigual a que, por amor a um princípio, vinha êle assistindo impassível.

Essa marcha, rumo a um ideal de justiça, tem sido mais ou menos lenta e já dura cêrca de um século e meio, podendo a sua história ser dividida em quatro grandes fases, cada uma tendo por ponto de partida um acontecimento de irrecusável repercussão por cial. A primeira delas vai, como assinalam GRANIZO e ROTHVOSS, das primeiras leis concernentes ao problema do trabalho até a pu' blicação do manifesto de Marx e Engels em 1848, marco inicial do segundo período, que se estende até a Conferência de Berlim, em 1890, e a publicação da encíclica "Rerum Nevarum", de Leão XIII, em 1891. O terceiro período data dessa época até o Tratado de Versalhes, em 1919, que é o ponto de partida do atual ciclo do direito trabalhista $\left({ }^{12}\right)$.

As primeiras legislações comerciais codificadas e, entre elas, a do Brasil, foram elaboradas durante a primeira fase dessa evolução, fase em que, pròpriamente, não se podia, ainda, falar em legislação do trabalho e que é, por assim dizer, a prehistória do direito ope rário. Além da lei inglêsa de 1802 , sem dúvida a primeira de índole realmente social, proibindo o trabalho noturno dos meninos nas fá bricas téxteis e fixando-lhes a jornada em 12 horas, limitacóes es. tendidas, mais tarde, em 1819, aos trabalhadones menores de quat quer indústria e alteradas, em 1825 ,om a reduca menores de qual11,30 hora da jornada para balho de menores e mulh , na França, em 1841, e na Itália, em 1843, nada mais digno de destaque pode ser assinalado nesse primeiro período da história da legislação do trabalho, que se caracteriza especialmente pelo fato de que "se muestran las leyes sociales como hechos aislados en ciertas naciones, bidos a sugestiones filantropicas" $\left({ }^{13}\right)$.

\footnotetext{
24 e 2 segs. L. MARTIN-GRANIZO e M. GONZALEZ-ROTHVOSS - Derecho Social, pags.

(13) Obr. cit. - pág. 24
}

Não obstante, já então, a situação angustiosa das classes operárias reclamar medidas governamentais que pusessem côbro sôbre à miserável espoliação que se processava às vistas dos podêres públicos, difícil se fazia, naqueles períodos da história, a promulgação de leis protetoras do trabalho, não só como decorrência da mentalidadé anti-intervencionista ainda em pleno fulgor, como também por ser cornente então a crença de que a nação que se dispusesse a estabelecer limitações no campo do trabalho veria cedo refletir-se essa sua atitude num decréscimo de produção, com perniciosas repercussões no páreo da concurrência econômica com os demais países.

Nessa persuasão, que os fatos vieram mais tarde mostrar ser errônea, os Estados se recusavam a intervir no choque tremendo entre o capital e o trabalho, o que levou certos espíritos mais avançados, apiedados da situação do proletariado, a lutar por uma legislação internacional do trabalho $\left({ }^{1 *}\right)$.

Foi, pois, nesse ambiente de escassas iniciativas legais com relação ao problema social, em quase todos os países do universo, que se processou a elaboração do nosso código de comércio e daqueles que the serviram de modêlo.

III

AVANCOS SOCIAIS DOS CÓDIGOS

MERCANTIS DA ESPANHA, PORTUGAL E BRASIL

Não pode deixar de surpreender àquele que estuda hoje a obra dos legisladores comerciais de há mais de um século a quase presciência cmo que foram encarados determinados aspectos das relações jurídicas que vinculam os chamados prepostos comerciais aos seus empregadores. E essa agudeza é tanto mais notável quanto é certo que, estabelecendo normas destinadas a reger relações entre individuos maiores e capazes, feriam de cheio o tabu da autonomia plena das vontades contratantes, numa época em que apenas alguns poucos turibulários menos exaltados dessa soberania da vontade concordavam em transigir, exclusivamente quando se tratasse de contratante menor. Essa transigéncia, no terreno do direito positivo, se corporificara, até então, num único diploma legal conhecido, a lei inglesa de 1802 , com as ampliações de 1819,25 e 33 , e só bem mais tarde se manifestou, na legislação de outros países, como a Alemanha, em 1839, a França, em 1841, a Itália, em 1843, a Espanha, em 1873,

(14) Robert Owen, filantrópieo industrial inglês, dirigiu-se en 1.818 às potên. thas reunidas em Aix-la-Chapelle, pedindo a adoca de leis internacionais para o trabs. por idêntico desideratum. 
a Bélgica, em 1884, Portugal, em 1889, etc., em todos êles, por conseguinte, posteriormente ao processo de feitura daqueles códigos.

Das três codificações em que se esteou o legislador brasileiro, à espanhola cabe a primazia na adoção de medidas de tutela aos prepostos comerciais, muito embora, não lhes atribuindo caráter imperativo, com o admitir pacto em contrário, haja o legislador espanhol, a nosso ver, perdido, em grande parte, as honras de precursor da moderna legislação social, que já the foi atribuída ( ${ }^{15}$ ), em favor do legislador brasileiro, a quem cabe o mérito de haver suprimido aquela condição restritiva à aplicação das normas em aprêço, que lhes emprestava caráter opinativo.

Não se conhecem, precisamente, quais os motivos que inspiraram ao legislador ibérico aqueles preceitos, dizem ALIOMAR BALEEIRO e LUIZ VIANA FILHO, no seu interessante trabalho sôbre "O direito dos Empregados no Comércio" ( $\left.{ }^{16}\right)$, interessante e precioso para o estudo da situação jurídica do preposto comercial no direito brasileiro, o qual, além disso, tem o duplo merecimento de ser a primeira e talvez única monografia sôbre o assunto publicada no país e de ter vindo à luz numa época em que problemas dessa espécie ainda não atraíam a atenção dos nossos juristas.

Embora renha sido o código espanhol calcado no Código Comercial francês de 1807, as mencionadas disposições, que dêsse não constavam, constituíram, naquele, inovações, atribuíveis, talvez, a ligeiras sugestões existentes na obra de PARDESSUS (17), cuja primeira edição surgiu em 1814, e aproveitadas pela comissão composta de Porcil, Pellegrin e Ballarino, encarregada, por Fernando VII, em 1827, de preparar a codificacão comercial espanhola (18). A inserção de tais dispositivos cresce de mérito quando é sabido que, a êsse tempo, o código comercial russo reconhecia aos comerciantes o direito de impor correções domésticas aos seus empregados.

O legislador português de 1833 , embora se haja limitado a compilar tais preceitos do código espanhol, mesmo assim merece louvo-

(15) ALIOMAR BALEEIRO e LUİZ VIANA FILFO - 0 direito do ILmpre-

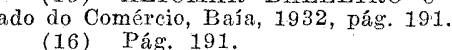

(17) Cours de Droit Commercial.

(18) A. BALEETRO e L. VIANA FILHO - ob. e loc. cits. - Segundo GELLA, "deseando las Cortes unificar el Derecho Español, en estado poco armónico después de la publicación de la Novíssima Recopilación, se nombrón, en las de 1810, una comision para que redatara un proyecto de Codigo de Comércio, que no pudo terminar su ca-
metido por las vicisitudes constitucionales de la epoca. Renació la idea en 1820 , y una nueva comision fué designada, sin que de ella saliera tampoco el tan deseado cuerpo legal; asi as cosas, em 1827 don Pedro Sainz de Andino elevó una exposición al Monarca rasu parte, la redacción de un Código de Comércio; y llevado a cabo su propósito, el

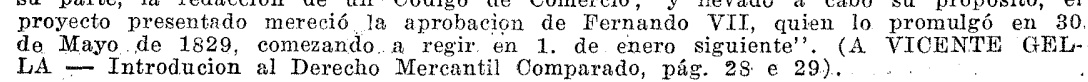

res por haver admitido e perfilhado normas que teria certamente res por haver admitido deixado empolgar pelo espírito da época. repelido se se houvesse deixado empolgar pelo espirito da época.

Por seu lado, o código brasileiro, expungindo aquelas normas do seu principal defeito, que era só thes dar validade na hipotese de siibérico.

O estudo detido da posição tomada pelo Código de 1850 , com relacão a diversos problemas que são objeto dos mais agitados derelação a diversos pros concepçóes que o direito do trabalho há forbates, à luz das novas concepçoes que dra de desenvolvimento da mulado, dar-nos-á melhor idéia do alto grau de desenvolvimento da mentalidade que presidiu à sua feitura e da

dos seus autores, a respeito de tais problmas.

Essa singular atitude do legislador de cem anos atras tem um sentido de certo modo profetico ,que, como desprezada pelos cultores dêsse moderno direito.

A) A questão da natureza juridica da relação de trabalho

Desde algum tempo se vêm travando, no campo do direito social acirrados debates em tômo da natureza jurídica da relação individual do trabalho. Para uns, ela, na sua essência, conserva dividual do trabalho. Pão sendo a circunstância de estar hoindole contratual prinitiva, não sendo a circunstane la despoja dêsje sujeita a intensa e variada regulamentaçán que lhe despoja desle se carater. Acham outros que, have o conteúdo patrimonial da aspectos eminentemente pessoaŕs sobre onquadrá-la no sistema contrareferida relação, não será possível enquadrá-ia no sistema contidetual clássico, e, por isso, dão-lhe um caráter institucional, conside tual clásico, exploraço ou unidade rando a empresa como uma comúda do chefe, que é o empregador econômica hierarquizada, constituida do chefe, que

e do pessoal, que é o agrupamento dos empregados.

Essa noção de comunidade hierarquizada decorre, proxima dois últe, das concepçóes polícicas que loresceram na turopa nos direito positivo timos decênios e foi especialmente consagrada no direito positivo alemão, durante o regime nacional-socialista, onde a empresa era dirigida por um Fuhrer, a que

devia obediência e respeito.

Esse princípio de chefia ou Fuhrer-prinzip encontra seu fundaEx formulada pelo direito germânico da comunhão mento na concepção formulada pelo direito ầ da produção, como de interêsses e aspirações entre os dois tatôres da produção, como uma réplica à teoria socialista da luta de classes, por isso que, no entender de POLO, um dos técnicos do anti-contratualismo, não basta, para suprimir a arraigada noção de luta de classe e mudar fisiono o deslocar-lhe o centro de gra- 
vidade do campo dos direitos patrimoniais para o terreno dos direitos pessoais $\left({ }^{19}\right)$.

Muitos outros juristas, contudo, sem qualquer relação doutrinária com as concepções político-jurídicas totalitárias, negam à lação de emprêgo o caráter estritamente contratual e entre êles se contam os que receberam a influência do institucionalismo de HAUde MADRID de MADRID, que tentou formular uma teoria especial da instituição sui-generis $\left({ }^{20}\right)$, vale mencionar, ainda, SCELLE $\left({ }^{21}\right)$ e DE

Por mais ousada que pareça a assertiva, um exame cuidado da sistemática adotada pelos autores do nosso Código de 1850 revelá que êles, deliberadamente ou não, já naquelas recuadas eras da primeira metade do século passado, tomaram posição com respeito ao problema da natureza jurídica das relações entre os comerciantes e seus prepostos, o qual, só muito mais tarde, polarizou o interêsse doutrinário dos juristas. Essa é, sem dúvida, a conclusão a que se pode chegar, observando-se a disposição adotada pelo Código, com referência à questão dos prepostos comerciais.

Efetivamente, reservando vários títulos de sua primeira parte - Do comércio em geral - aos contratos e obrigaçóes mercantis (Títulos V e sgs.), preferiram, os responś́ e obrigaçōes mercantis incluir entre êsses a preposição mercantil, situando a regulamentação dos prepostos e demais agentes auxiliares do comércio logo em seguimento aos capítulos sôbre os auxiliares do comércio logo em seguimento aos capítulos sôbre os comerciantes e praças de comércio. Essa integração virtual dos agentes auxiliares do comércio ao negócio condiz com as teorias modernas de comunidade da emprêsa.

Convém ainda frisar que essa integração resulta na sistemática de nosso Código, não só da disposição dada às matérias, como das próprias expressões legais que revelam ter sido êsse o propósito deliberado do legislador. Veja-se, verbi gratia, no artigo 74 , o prêgo da expressão "prepostos das casas de comércio" e a exigência de uma nomeação que "devem receber de seus patróes ou preponentes", como título de sua investidura, ao invés do instrumento do contrato.

O eminente CARVALHO DE MENDONÇA pôs em destaque essa faceta do nosso Código Comercial, louvando-lhe o acêrto, pois considera o sistema digno de aplausos, uma vez que com referên ca a êsse assunto, há predominância do caráter pessoal, embora exis-

(20) ANTONIO POLO - Del contrato a la relación de trabajo, pág. 79 . (21) ALFONSO MADRID - Derecho laboral español, 1936, págs. 221 e segs.
(21) GEORGE SCELIE - Précis de Legislation Industrielle, pags. 173 e segs. Le Droit Ouvrier, págs. 108 e segs.
(22) MARIO DE LA CUEVA - Derecho Mexicano del Trabajo, tomo I, pág. ta algo de contratual. E, a propósito, afirma aquêle nosso grande comercialista, ser feliz o emprêgo da expressão "prepostos das casas de comércio", a qual "bem traduz a posição dos empregados no comércio, elementos dessas casas" $\left({ }^{23}\right)$.

E' bem de ver, entretanto, que êsse critério adotado pelo legislador brasileiro, como pelos que elaboraram os códigos estrangeiros que lhe serviram de molde, é um remanescente das antigas relações que ligavam ao comerciante o seu pessoal auxiliar e que tinham sua origem, não nos quadros romanos do contrato de locacão, mas naquele outro, de assinalável sabor medieval, dos chamados serviços fiéis, de origem germânica (Treudienstroentrag). Segundo GARRIGUES, a emprêsa mercantil da época precapitalista constituía antes uma comunidade doméstica de trabalho que, quando não se fundava em vínculos de sangue, tinha sua base em vínculos de proteção ao empregado e de confiança recíproca entre êsse e o comerciante ${ }^{(24)}$. Foi nesse regime de subordinação hierárquica e de lealdade e respeito mútuo, característico das antigas "encomendaciones" espanholas da época visigótica, que inspirou, em parte, a moderna conceituação de relação do trabalho, em que, certamente, foram abeberar-se, nesse particular, os códigos comerciais da primeira metade do século XIX.

\section{B) As garantias do direito ao emprêgo}

Uma das modificações trazidas pelo direito do trabalho às regras tradicionais que informavam os ordenamentos jurídicos foi a imposição de restrições á ruptura dos contratos de duração indeterminada.

A soberania da vontade, elevada à condição de regra inflexível, tinha como consequiência imediata a escravização dessa mesma vontade à fôrça obrigatória dos contratos, pois, no sistema jurídico liberal, o indivíduo é livre para celebrar o contrato e, desde o instante em que o celebra, é escravo dêsse mesmo contrato.

Como corolário dessa regra do pacta sunt servanda, fixado um prazo de permanência das regras pactuadas, êsse teria de ser estritamente comprido até final, pouco importando que, pela superveniência de motivos os mais justos, a vontade atual de um dos contratantes não coincidisse mais com a vontade inicial, expressa na conclusão do contrato. Da mesma forma, estabelecida no contrato, pela não fixação de um prazo certo de duração, a faculdade de rom-

(23) J. X. CARVALHO DE MENDONGA - Tratado de Direito Comercial Brasileiro, vol. II, pág. 435.
(24) GARRIGUES - Del viejo Derecho Mercantil al nuevo Derecho del Trabajo, pags. $61 / 2$. 
pê-lo a qualquer momento, não seria possível obrigar a sua continuação, quando uma das partes desejasse desvencilhar-se do vínculo, ainda que a justiça, a eqüidade ou mesmo as necessidades da ordem social reclamassem a sua conservação.

Foi justamente no direito do trabalho onde se fez sentir com mais intensidade a tendência moderna para atenuar os êrros dessa construção clássica, abrandando a rigidez daqueles princípios, num como retôrno ao direito dos canonistas e teólogos da Idade Média, que vedava as explorações à sombra do contrato, a chamada injustiça usurária, pois, como afirmava BOSSUET, no seu "Sermão sôbre a justiça", "la justice veut qu'on ait égard non seulement à l'obligation, mais à l'état de celui qui doit".

Um dos sinais da insurreição contra o rigor do princípio da soberania da vontade, que se vem processando através das novas concepçôes jurídicas, vamos encontrar nas restrições, cada vez mais severas, à rescisão arbitrária do vínculo contratual do trabaho, mesmo quando estabelecido sem prazo certo. Essas restrições, que já hoje atingem, em certas hipóteses, a supressão total da faculdade de partir a relação que o velho direito assegurava plenamente às partes, nos contratos sem duração decerminada $\left({ }^{25}\right)$, tiveram suas primeiras manifestações nos códigos comerciais promulgados depois do Código francês, com o proibirem-se, por disposição expressa, os rompimentos bruscos das relações entre o comerciante e os seus prepostos, isto é, sem ciência prévia da outra parte contratante, com o prazo mínimo de 30 dias.

Esse princípio, ainda hoje inscrito em tôdas as legislaçôes sociais dos povos cultos, embora mais circunstanciadamente regulado, constituindo o chamado instituto do aviso prévio, representa um notável avanço para a época em que foi formulado, uma verdadeira inovação jurídica, das mais singulares, sem dúvida, para o tempo, e, certamente, de difícil justifiçação e entendimento, dada a sua inadequação às nascentes filosóficas que informavam todo o ordenamento jurídico de então.

Para fazer-se melhor idéia de quanto madrugaram, nesse terreno, os legisladores mercantis daquela época, basta que se atente para a circunstância de que o nosso Código Civil, elaborado quase 70 anos depois, foi, a êsse respeito, bem mais parcimonioso, cingindo-se a estabelecer, nas chamadas locações de serviço, o preaviso de oito, quatro e um dia, conforme a periodicidade de pagamento do salário ( $\left.{ }^{26}\right)$.

$\frac{\text { (25) A estabilidade no emprêgo, depois de um decênio de casa, é um exemplo da }}{\text { abolicăo total dessa faculdade. }}$ (26) Código Civil, art. 1-221 e \& único.
C) Proteção do empregado nos infortúnios imprevistos e inculm pados.

Talvez, dos chamados favores legais do Código Comercial de 1850 aos empregados do comércio seja o contido no artigo 79 o que encerre maior sentido social.

Efetivamente, quando o legislador, naquele preceito, estabeleceu que cabia aos empregadores a obrigaçấo de assegurar aos seus prepostos os respectivos salários, até três meses consecutivos, no caso de qualquer acidente imprevisto ou inculpado impedi-los de exercer as suas funcóes, teve em mira oferecer um amparo efetivo ao empregado, nos momentos em que, por motivos alheios à sua vontade, fica êle privado do seu ganho normal.

Inegàvelmente, mais do que a respeito de qualquer outra das obrigaçoes prescritas aos comerciantes para com os seus prepostos, obrigaçoes ordem social devem ter impelido os arrojados legisladores comerciais da época a consignar tal norma na legislação positiva, embora transcendendo as lindes da construção contratual então prevalente.

Sendo pacífico, ao tempo, resultar a relação de emprêgo de um contrato tipicamente comutativo, em que a contraprestação de um dos contratantes está condicionada à prestação por parte do outro, isto é, em que o pagamento dos salários vale cono preço do serviço fornecido e, sem a prestação dêste, a contraprestação daquele não seria exigível, a obrigação de pagar salários sem receber serviços constitui uma violência à estrutura jurídica erigida sôbre tais fundamentos.

Modernamente, com o desenvolvimento da política social, se tem procurado encontrar o fundamento jurídico dessa proteção ao empregado, durante os infortúnios não oriundos do trabalho, no princípio de que o salário não será jamais o preço justo do serviço prestado, enquanto o seu valor não fôr suficiente para atender, além das necessidades imediatas e atuais do trabalhador, as do tempo em que, por fatores estranhos à sua vontade, fique êle impossibilitado de traballar.

Os comentadores de nosso Código Comercial, tendo à frente CAR$\checkmark$ ALHO DE MENDONCA, o maior de todos, vêm naquela disposicão da nossa lei comercial uma resultante do caráter de alimentos que têm os salários, de onde a conveniência de impor o seu pagamento independentemente đa prestação de serviços, nas hipóteses de acidentes imprevistos e inculpados, em que aquêle eminente comercialista faz compreender, por eqüidade, os dias de nojo e bodas e aquê- 
les em que o preposto tiver de desempenhar deveres cívicos ou serviços públicos honorários $\left({ }^{27}\right)$.

\section{D) Ressarcimento dos danos extraordinários}

O artigo 80 do Código Comercial brasileiro e o artigo 202 do antigo Código Comercial espanhol são, sem dúvida, os mais antigo precedentes legislativos de que há notícia, com referência ao problema dos acidentes do trabalho.

Nesse passo, como nos demais, o legislador nacional e o legislador espanhol, aquêle talvez mais do que êste, pelos motivos que mais adiante mostraremos, revelaram-se avançados em várias décadas a respeito de questões que, até então, longe estavam de preocupar a atenção dos responsáveis pelo destino das sociedades.

Sabe-se que data de pouco mais de setenta anos a evolução das teorias relativas à responsabilidade pelos danos decorrentes dos infortunios do trabalho e que essa evolução envolve uma "das transformações mais radicais nas idéias primitivamente dominantes. Comentando-a, diziam CAPITANT e CUCHE, há vinte anos: "Nous rencontrons ici un des exemples les plus interessants des changements que peuvent se produire dans les idées morales des hommes". E acrescentavam: "Il y a cinquante ans, ancune législation n'admettait que le chef d'entreprise fût, comme tel, et abstraction fait de toute faute commisse par lui ou ses préposés, obligé de réparer les conséquences dommageables des accidents" $\left({ }^{28}\right)$.

A teoria do risco profissional, hoje geralmente aceita e adotada em quase tôdas as legislações, chegou a ter o seu reverso admitido em países como a Inglaterra, que fazia, em todos os casos, recair o risco sôbre o operário, isentando de qualquer responsabilidade o patrão, sob o fundamento de que se presumia haver aquêle, ao contratar-se, assumido todos os perigos inerentes à sua profissão e envolver o salário o prêmio referente a êsse risco.

Antes da legislação alemã de 1884 , a primeira a perfilhar a teoria do risco profissional, a matéria de acidentes era regulada pelos princípios de direito comum concernentes à responsabilidade civil, com a aplicação, por largo tempo, da teoria tradicional da culpa subjetiva ou aquiliana, segundo a qual, sòmente nos casos de acidentes em que ficasse provada a negligência ou imprudência do patrão, lhe seria imputável a responsabilidade dos danos sofridos pelo operário.

Contrariando essa tese, que se manteve em pleno fastígio na doutrina e na jurisprudência até as vésperas do último quartel do século

(27) Ob. e vol. cits. págs. $453 / 4$ passado, dispôs, em 1850, o nosso Código Comercial que, "se, no serviço do preponente, acontecer ao preposto algum dano extraordinário, o preponente será obrigado a indenizá-lo, a juízo de arbitradores" (29).

Não cogitou o legislador comercial de saber se o dano sofrido pelo empregado resultou de culpa do empregador, condicionando a responsabilidade dêste apenas ao fato de ocorrer o acidente no seu serviço. Ainda mais: não excluiu do âmbito de ação dêsse dispositivo os danos para os quais o preposto contribuisse com culpa. Um confronto entre aquêle dispositivo e o artigo 79 torna evidente ter sido êsse o propósito do legislador, pois, para os casos previstos nesse último, impôs tal condição, quando se referiu a "acidentes inculpados", ao passo que silenciou quanto ao primeiro.

Cumpre ainda ressaltar que, enquanto o dispositivo correlato do código espanhol onde o nosso legislador foi buscar a inspiração para a regra em aprêço, só abrangia os acidentes que resultassem imediatamente do trabalho, isto é, "por efecto immediato y directo del servicio" $\left({ }^{30}\right)$, o código nacional apenas exigia que o acidente se desse no serviço do preponente, o que, inquestionàvelmente, estendeu $\mathrm{o}$ âmbito de aplicação da lei brasileira, envolvendo os acidentes ocorridos durante a prestação de trabalho, embora não originados direta e imediatamente dêste.

Para ALIOMAR BALEEIRO e LUIZ VIANA FILHO ( $\left.{ }^{31}\right)$, os fundamentos jurídicos dessa avançada disposição da nossa legislacão mercantil codificada só podem ser encontrados na teoria da responsabilidade objetiva (du fait des choses), muito mais tarde idealizada por SALEILLES e JOSSERAND, enquanto, para JORGE AMERICANO, tem ela os mesmos fundamentos da moderna teoria do risco profissional $\left({ }^{32}\right)$.

Por sua vez, BENTO DE FARIA, comentando essa disposição, admite que a indenização nela prevista independe da concorrência de culpa por parte do preponente, aceitando assim tenha sido a noção da culpa objetiva, só muitos anos mais tarde desenvolvida, a inspiradora de tal preceito $\left({ }^{33}\right)$.

Evidentemente, em face dos termos daquele dispositivo, a obrigação de ressacir os danos ocorridos no serviço não está condicionada à prova da culpa do patrão, nem tampouco desaparece nas hipóteses de culpa do preposto ou de caso fortuito.

Tais conclusões, que aquela recuada disposição legal comporta, sem qualquer violência à sua letra ou ao seu espírito, só se tornaram

(28) HENRI CAPITANT e PAUL CUCHE - Précis de Legislation Industrieł.

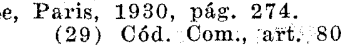

(30) Cód. Com. espanhol de 1829, art. 202.

(31) Ob. cit., págs. 207 e segs.

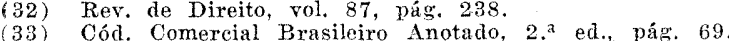


possíveis, quanto aos acidentes do trabalho em atividades por ela não compreendidas, com o advento das teorias relativamente recentes da responsabilidade pelo fato das cousas e do risco profissional, que informam, hoje em dia e somente de alguns anos a esta parte, as diversas legislações específicas das nações civilizadas.

Que maior galardão, pois, poderia reivindicar o nosso arguto legislador comercial da primeira metade do século passado?

\section{E) A irrenunciabilidade dos direitos do empregado.}

Há, entretanto, um aspecto do problema que vem prendendo a nossa atenção, no presente trabalho, que merece destaque especial. Quanto a êle, as honras que, por justiça, têm sido, até aqui, repartidas entre o legislador nacional e os autores dos códigos espanhol e português, de 1829 e 1833, respectivamente, cabem, por inteiro, aos responsáveis pela feitura do nosso grande estatuto legislativo de 1850 .

Se a inspiração para os preceitos de natureza social que vimos estudando até aqui, o legislador brasileiro a foi beber nos citados có digos ibéricos, a alteração substancial que êle imprimiu a tais preceitos, deu-lhes caráter original, e emprestou-lhes o aspecto de verdadeiras prescrições de tutela, de natureza perfeitamente assemelhável à que caracteriza as atuais legislações protetoras do trabalho.

As correspectivas disposições daqueles dois códigos, incluindo no seu texto uma cláusula tendente a permitir a sua derrogação através de convenções privadas, elidiram, em grande parte, as vantagens sociais que poderiam advir da sua aplicação, e, assim, perderam, quase radicalmente, o caráter de normas de legislação do trabalho, dentro do seu moderno conceito. As referidas normas, por conseguinte, dificilmente poderiam ser incorporadas, sem dissonância, ao que atualmente se convencionou chamar legislação social, o que, fora de qualquer dúvida, não ocorre com as correspondentes disposiçôes do código
brasileiro.

Senão vejamos.

O artigo 201 do Código Comercial espanhol de 1829, matriz dà disposição análoga do Código Comercial português de 1833 e do artigo 79 do nosso Código, estabelece que não interromperão a percepcão de salário, até três meses, os acidentes imprevistos e inculpados que impeçam os gerentes e prepostos de desempenhar o seu serviço, e acrescenta de maneira expressa: "como no haya pacto em contrario".

Também o artigo 202 daquele mesmo Código, fonte do art. $80 \mathrm{da}$ nossa lei comercial, dispóe que cabe ao empregador indenizar o empregado, se, por efeito imediato e direto do serviço que preste o preposto do comércio, experimentar êle algum gasto extraordinárió ou perda, "sobre cuya razón no se haya hecho pacto expreso entre él y su principal".

Fazendo-se o confronto entre o preceito nacional e a regra legal estrangeira, nos dois casos, observa-se, de logo, que o legislador brasileiro excluiu as condiç̃es" como no haya pacto en contrario" e "sobre cuya razón no se haya hecho pacto expresso entre él y su principal".

Não se poderá jamais, de boa fé, negar que essa dupla exclusão foi deliberadamente levada a efeito, com o propósito de afastar a possibilidade de estabelecer-se, por pactos privados, condições diversas daquelas que o legislador achou de bom alvitre impor aos contratantes, na constituição do vínculo de emprêgo.

O espanhol de 1829 e, depois, o luso que lhe seguiu as pegadas legislaram para a hipótese do silêncio do contrato, da abstenção dos convenentes com relação à matéria. O legislador brasileiro instituiu normas aplicáveis a qualquer contrato, dispusesse ou não sôbre o assunto, por isso que, se êle pretendesse admitir convenção em contrário ao disposto nos referidos artigos, teria reproduzido na íntegra os preceitos que utilizou por modêlo.

Assim agindo, deu-lhes, àqueles direitos que conferiu aos empregados do comércio, um caráter que hoje é condição essencial para a eficiência de qualquer norma trabalhista, a irremunciabilidade por convenções privadas.

Resultante lógica do princípio da desigualdade econômica entre os dois agentes da produção, a inderrogabilidade por pactos privados das normas de proteção ao trabalho, ou a irrenunciabilidade a essa proteção constituiu a melhor garantia de eficácia da tutela estatal ao econômicamente fraco, que, em razão de suas próprias condições, pode ser coagido a abdicar dessa proteção.

Emprestando, por conseguinte, o caráter de irrenunciáveis aos direitos atribuidos aos prepostos no comércio pelos arts. 79, 80 e 81, - nosso vetusto Código Comercial alteou-se sôbre os seus congêneres e revelou, mais a êsse respeito do que quanto aos demais, a profunda agudeza intelectiva de seus autores, a ponto de aflorar problemas que sòmente depois de mais de meio-século vieram à tona dos debates, solvendo-os com maravilhosa intuição e notável felicidade $\left({ }^{34}\right)$.

(34) Para não alongar o presente trabalho, deixamos de focalizar outras dispoparte geral, quer na os dos arts. 547 e 560 que apresentam estreita analogia com os princípios dos arts. 80 e 79 , respectivamente. 


\section{IV}

\section{INDICE DA MENTALIDADE QUE PRESIDIU À FEITURA DO CÓDIGO DE 1850}

A investigação histórica que vimos empreendendo, talvez mais extensamente do que se fazia necessário, já a essa altura nos permite formular a primeira conclusão que pretendemos extrair dêste estudo. E' essa primeira conclusão a de que, feita a análise do estado em que se encontravam os estudos relativos aos problemas oriundos das redigo Comercial, e que o legislador de 1850 precisou regular no Cópectos, a quase antevisão a penetrante acuidade e, sob certos aspectos, a quase antevisão do direito do futuro com que soube fazêlo, imprimindo-lhes diretrizes que, se houvessem logrado aplicação, teriam dexado o empregado do comércio no Brasil em situação altamente privilegiada com relação aos demais trabalhadores dos diversos países, vale êsse fato como um seguro índice da mentalidade que presidiu à elaboração do nosso centenário Código Comercial.

Efetivamente, mais perfeita medida não seria possível obter para aquilatar o gráu de arejamento do espírito que norteou a nossa primeira lei codificada, não bastasse a circunstância, já antes salientada, de haver ela atravessado airosamente um século da nossa existência, sem que o retardamento no preparo do futuro Código Comercial brasileiro houvesse, até agora, importado em malefício irremediável.

A perspicácia e o discortínio mental com que os autores do nosso venerando Código encararam tais problemas os autores do nosde estar presentes a todo o restante problemas não podiam deixar cometida, mòrmente quan o restante da obra legislativa que lhes for devem ter mormente quando, a respeito das demais questões a solver, devem ter contado com copiosos elementos de estudo, que, decerto,

Não se obje tange às relações de trabalho.

anos, das disposicóes a a ineficácia prática, durante cêrca de oitenta anos, das disposições acima apreciadas lhes reduz o mérito e, conseqüentemente, invalida a conclusão. Realmente, não lograram tais por social. Mas nisso não êles letra morta, sem qualquer significação social. Mas nisso não vai qualquer culpa do legislador e, muito ao tese que defendemonstância induz a novo argumento em favor.da

Com efeito, a inaplicação dos dispositivos sociais do Código Co-
ercial de 1850 nada mais é do mento entre a mentalidade do que uma conseqüência do desajustarefratária a qualquer fantade dominante, retrógada e essencialmente refratária a qualquer fantasia intervencionista, e o elevado alcance de
taispositivos. Mergulhado ainda o país num regime econômico escravagista, que perdurou por cêrca de quarenta anos após a promulgação daquele monumento legislativo, é perfeitamente compreensível essa reação a qualquer tentativa de proteção ao trabalho livre, que, àquela época, ensaiava os primeiros passos no país, se livre se pudesse chamar o trabalho dos nossos antigos empregados do comércio, sujeitos a um regime de verdadeira servidão.

"Os favores legais dos arts. 79, 80 e 81 do Código tiveram a sorte das plantas exóticas quando removidas da estufa para a inclemência do ambiente hostil: jamais foram concedidos", afirmam BALEEIRO e VIANA FILHO, e, logo a seguir, acrescentam: "Não poderiam medrar num país, como o Brasil, que, àquele tempo, incluia a escravidão entre as suas instituições nacionais" $\left({ }^{35}\right)$.

Tal foi o estado de letargia em que permaneceram aquelas normas, durante longos anos esquecidas, por falta de qualquer apoio administrativo ou judicial aos interessados, que, ao vir êsse apoio, com a criação do Ministério do Trabalho, em 1930, e, ante as primeiras tentativas de aproveitamento do conteúdo social daquela antiga legislação, por tantos anos latente, chegou a ser levantada a tese de que estava ela abrogada, pelo longo desuso em que jazera.

Esse fenômeno, entretanto, repetimos, não exclui, nem sequer torna menor o merecimento de seus autores. Muito ao contrário, mostra o quanto se haviam êles alçado sôbre meio em que viveram, dando-nos uma singular legislação que, oitenta anos depois, quando a mentalidade ambiente se transformou, pôde ser aplicada com absoluta atualidade.

$$
\text { V }
$$

\section{CAUSAS JUSTIFICATIVAS DA INCLUSÃO DE NORMAS DE LEGISLAÇÃO SOCIAL NOS ANTIGOS CÓDIGOS MERCANTIS}

Nessa ausência quase total, à época de elaboração dos códigos comerciais do século passado, de qualquer norma de proteção aos econômicamente fracos, na partida desigual do acêrto de condições contratuais, reside a maior justificação da atitude do legislador de então em não deixar inteiramente ao desamparo aquêles que, constituindo como que o estado maior do comerciante, são os principais colaboradores do desenvolvimento de seus negócios e elementos imprescindíveis à consecução do fim que êle colima com a sua atividade.

Fenômeno análogo vamós encontrar com relação ao direito civil, que também sofreu sensível penetração por parte de nosso Código Comercial dando aso às críticas que lhe foram dirigidas por Joaquim 
Antão Fernandes Leão e Bernardo Vasconcelos, na Assembléia Le. gislativa, e, mais tarde, por TEIXEIRA DE FREITAS. Essa. incursão, entretanto, era da mesma forma explicável, pela inexistência, no país, de uma codificação civil.

Cumprindo-the regular as relaçôes jurídicas provindas do exercício do comércio, em seus múltiplos aspectos, inclusive quando tais relações se processam através dos mandatários ou prepostos do comerciante, é perfeitamente lógico que se preocupasse o legislador também das relações entre o comerciante e êsses prepostos, não só para definir as respectivas responsabilidades decorrentes da atividade comercial, como ainda para fixar os direitos e deveres recíprocos, que emanam do vínculo contratual que os une, visto como, até então, essa matéria escapava completamente a qualquer espécie de regulamentação específica. Acresce ainda que, até aquela época, nâo existia qualquer diferenciação conhecida entre a natureza jurídica dêsses direitos e obrigações e a dos demais direitos e obrigações regulados pelo Código. Pelo contrário, procurou-se sempre acentuar a similitude entre essas situaçóes, equiparando, para os fins legais, os chamados agentes auxiliares dos comerciantes a êstes, como o fizeram - Código espanhol de 1829, estipulando que tais agentes "estan sujetos a las leyes mercantiles y con respecto a las operaciones que les corresponden en esta calidad" ( $\left.{ }^{36}\right)$, e o código português de 1833, quando estabelecia que seriam êles sujeitos às leis comerciais "como agentes auxiliares empregados no comércio e com relação às operaçôes que nessa qualidade lhes respeitam" ( $\left.{ }^{37}\right)$. De seu lado, 0 art. 35 do nosso estatuto comercial básico reproduz quase literalmenté aquelas expressões.

Além disso, querem os comercialistas ver no contrato de preposição mercantil, bem como nos atos de responsabilidade dos prepostos, atos de comércio por dependência ou conexão. Nesse sentido, opinam, além do ínclito CARVALHO DE MENDONÇA ${ }^{38}$ ), BALEEIRO e VIANA FILHO, salientando, embora, que autorizados mestres estrangeiros negam a qualidade mercantil ao contrato de preposição ou de emprêgo no comércio, entre os quais THALLER, que o considera de natureza puramente civil $\left({ }^{39}\right)$. Outros, como LYON-CAEN e RENAULT, o têm como um contrato de natureza mista, de dupla face, comercial, no que concerne ao comerciante, e civil, para o preposto $\left({ }^{40}\right)$.

Não é, por outro lado, de desprezar, como fator da incorporação de normas de regulamentação do trabalho aos códigos mercantis do

(36) Art. 62.

(38) Ob. citada, vol. I, n. 0 366, e, e 359 , g.
(39) Traité Elem. de Droit Commercial, n.. 29 .

40) Traité de Droit Cona., Tomo III, n. $0^{\circ} 251$ - Manuel de Droit Com. n.०500 princípio do século XIX, maximé do código espanhol de 1829 e dos que lhe seguiram a trilha, a influência que, naquela época, ainda exercia a noção de emprêsa mercantil da fase precapitalista $\left({ }^{41}\right)$, tanto mais quanto é sabido que o comércio se manteve, por muito tempo, circunscrito a um círculo mais ou menos fechado e, por conseguinte, pouco permeável aos exageros liberalistas que já avassalavam muitos outros departamentos da atividade humana. Essa peculiaridade se manifesta através de tôdas as legislações específicas da primeira fase do direito comercial, que então se caracterizava pela feição de direito de classe, a qual, modernamente, vai êle perdendo.

\section{VI}

\section{IMPROPRIEDADE DA INSERÇÃO DE MATERIA TRABA- LHISTA NUM CÓDIGO COMERCIAL MODERNO}

A inclusão de normas de índole tìpicamente trabalhista justificava-se, àquele tempo, em face, como vimos, não só da ausência de uma legislação específica, como da conexão, à época admitida, entre o contrato de preposição mercantil, como ato de comércio acessório, e os demais contratos em que toma parte o comerciante, e ainda como resultante da sobrevivência de um certo sentido de comunidade de trabalho, na emprêsa mercantil de então, que, de alguma forma, amanhara o terreno em que seriam lançadas as idéias que se corporificaram naquelas normas.

Entretanto, não será mais possível, hodiernamente, admitir-se, em sã consciência, êsse ecletismo, como não é mais aceitável a conservação num código mercantil moderno, de princípios de direito civil, como os concernentes aos contratos e obrigaçôes em geral, que o nosso código de 1850 inseriu no seu contexto.

Vitoriosa a idéia de códigos autônomos, em contrário ao pensamento daqueles que preconizavam a conveniência da codificação unificada do direito privado, não há por onde recusar o critério da delimitação exata do campo de jurisdição de cada código isolado, sem qualquer interpenetração ou ubicação de matéria, que sòmente desvantagens pode acarretar à sistematização dos ordenamentos jurídicos.

Como assinala ADAMASTOR LIMA "O Estado mantém a Ordem Política (Indivíduo e Propriedade), bem como a Ordem Econômica (Capital e Trabalho) e o Direito tem dois grandes objetos - a matéria civil (Direito Civil) e a matéria econômica (Direito capitalista e Direito trabalhista" $\left({ }^{42}\right)$.

(41) "D. pág. ... Comercial" in DIREITTo vol. XxxvII pág. 72 
Traçando as linhas distintivas dessa bifurcação do direito, com relação à matéria econômica, diz aquêle devotado e brilhante cultor do direito comercial em nosso país: "Direito capitalista é o ramo jurídico que regula a atividade econômica sob a tríplice manifestação de comércio, indústria e agricultura, visando, simultàneamente, à existência e à proteção do capital. Direito trabalhista é o ramo jurídico que regula a atividade assalariada das pessôas físicas, visando, simultàneamente, ao exercício e à proteção do trabalho" (43).

Primitivamente, os sistemas legislativos gravitavam exclusivamente em tôrno do patrimônio, como riqueza criada, relegando a um absoluto descaso o processo de formação dessa riqueza pelo trabalho. $\mathrm{O}$ curso dos anos, no entanto, e o agravamento acelerado dos males decorrentes dessa deficiência do direito tornaram instante a ampliação dos seus quadros e a invasão de novos setores de atividade em que êle então não havia penetrado ou havia penetrado mal, mòrmente no que se refere aos problemas econômicos e, particularmente, no que concerne à criação da riqueza pelo trabalho humano.

Essa ampliação, relativamente à proteção e regulamentação do trabalho, cada vez mais intensa, chegou a um tal estado que deu origem à formação de um ramo novo da ciência do Direito, como características absolutamente definidas, em tôrno de cuja autonomia já hoje cessaram as controvérsias.

Exteriorizado, em quase tôdas as nações civilizadas, por um sistema legal específico, cujos princípios informativos são substancialmente incompatíveis com aquêles que presidiram e hão de presidir à obra legislativa destinada a reger as relações jurídicas comuns, quer as civis, atinentes ao indivíduo e à propriedade, quer as capitalistas, que têm por escopo a situação do capital na sua atividade econômica, - o direito do trabalho já hoje tem seu âmbito de ação estabelecido com absoluta precisão, que impossibilita qualquer interferência ou ambiguidade.

Com res eito às relações de que participam os prepostos comerciais, um tríplice aspecto exige a atenção do legislador, a saber: a) relações entre o comerciante e terceiros, por intermédio de prepostos; b) relações dos comerciantes com os seus empregados, no que tange às mútuas responsabilidades decorrentes da atividade comercial do primeiro e participação dos prepostos nessa atividade; c) relaçóes de natureza estritamente trabalhista entre $o$ comerciante e seus prepostos.

Como é intuitivo, na formulação do novo estatuto para o comércio apenas os dois primeiros dêsses três aspectos poderão ser objeto de apreciação, por isso que o terceiro escapa totalmente aos obje-

(43) Art. e obsicits. tivos de qualquer legislação mercantil, por estar fora das linhas do direito comercial.

Não se procure argumentar com as distinções intrínsecas que podem ser encontradas num confronto entre o contrato de trabalho, como êle é genèricamente entendido, e o chamado contrato de preposição mercantil, porque tais diferenciações não chegam a justificar a deslocação dêsse último do campo do direito do trabalho para o do direito comercial. A preposição mercantil, na sua essência, nada mais é do que um contrato de trabalho, apenas mesclado, na mor parte dos casos, com uma maior ou menor dose de mandato ou representação, o que, no entanto, não o desfigura e, nem tão pouco, impõe tratamento diverso das normas legais de tutela ao trabalho. O que dessa especificidade pode interessar, para efeito de uma regulamentação à parte, são os dois primeiros aspectos acima indicados. Quanto ao terceiro, as peculiaridades que possam apresentar como figura jurídica não têm nenhuma importância ou interêsse para a sua regulamentação legal.

O Direito do trabalho visa à tutela do indivíduo que assalaria a outrem a sua própria força de trabalho, pouco importando a natureza dos serviços por êle prestados ou o setor da atividade econômica onde êle a emprega, seja na indústria, na agricultura, no comércio ou em qualquer outro. Desde que se cogite de regular essa relação jurídica, não é mais possível, hoje, fazê-lo fora do raio de ação do direito social.

Essa impropriedade da regulamentação do contrato de trabalho dos empregados do comércio nos atuais códigos mercantis é, pois, a segunda conclusão que pretendemos extrair do presente trabalho.

\section{VII}

\section{SINTESE E CONCLUSÕES}

Sintetizando o presente estudo, para encerrá-lo, vemos que:

1 - O Código Comercial brasileiro de 1850, fruto do trabalho de quase vinte anos, teve como principais fontes o código francês de 1807, o espanhol de 1829 e o português de 1833, principalmente o segundo.

2 - Referido código foi elaborado e promulgado numa época em que nada ou quase nada existia relativamente à tutela legal do trabatho em suas relações com o capital, sendo que as poucas leis até então conhecidas a êsse respeito, além de esparsas, eram devidas a movimentos de simples filantropia. 
3 - É, assim, surpreendente como o Código então promulgado, seguindo, em parte, as diretrizes dos códigos espanhol e português e mesmo superando-as, continha no seu contexto disposições que constituem notáveis avanços no campo da legislação social, entre os quais cumpre assinalar:

a) a integração dos prepostos comerciais ao negócio, constituindo como que um pronunciamento do legislador de 1850 em tôrno do já hoje debatido problema da natureza jurídica da relação de trabalho;

b) a instituição do preaviso de dispensa, como embrião das atuais garantias do direito ao emprêgo;

c) a garantia do salário dos empregados nos infortúnios imprevistos e inculpados, até o limite de 3 meses;

d) a obrigação de ressarcir os danos extraordinários ocorridos no serviço, manifestação embrionária da atual legislação sôbre acidente do trabalho;

e) a irrenunciabilidade atribuída a tais direitos pelo legislador brasileiro, quando excluiu das respectivas disposições do nosso código as cláusulas contidas nas normas estrangeiras correspondentes que permitiam a sua derrogação por convenção privada.

De todo o exposto, concluimos:

A penetrante agudeza com que agiu o legislador brasileiro de 1850 , inserindo tais normas no corpo do Código Comercial, serve de índice da mentalidade elevada que presidiu à sua elaboração, mesmo com relação ao restante daquela obra legislativa.

\section{II}

Embora explicável e mesmo louvável a intenção do legislador de cem anos atrás em incluir no contexto do Código alguns princípios de natureza social, hodiernamente essa inclusão não seria admissível, porque contrária à reconhecida autonomia do direito do trabalho, a que tais normas, necessàriamente, pertencem.

\section{B I B L I O G R A F I A}

AMERICANO (JORGE) - Parecer, in "Revista de Direito", vol. 87. AMERICANO (JORGE) ANAIS DO PARLAMENTO BRA da Câmara dos Deputados.

dsworth - Sessão de 1835 da Câmara dos Deputados. ANAIS DO PARLAMENTO BRASILEIRO, coligidos por Antonio

Reis - Segunida sessão de 1845 da Câmara dos por Antonio Pereira ANAIS DO PARLAMENTO BRASILEIRO, coligidos por Antonio Per.

Pinto - sessão legislativa de 1850 da Careito dos EmBALEEIRO (Aliomar) e VIA
pregados no Comércio.

ERGSON - L'évolution créatrice.

BERGs (Précis de Legislation Industrielle.

CAYRÚ (Visconde de) - Princípios de Direito Mercantil e Leis da ma-

rinha.
CUEVA (MARIO DE LA) - Derecho Mexicano del Trabajo.

FARIA (BENTO DE) - Código Comercial Brasileiro Anotado.

Ferecho Mercantil al nuevo Derecho del Trabajo.

GRANIZO (L. MARTIN) e ROTHVOSS (M. GONZALEZ) - Derecho Social. LIMA (ADAMASTOR) - Direito Comercial, in "Direito", vol. XXXVIr.

LYON-CAEN e RENAULT - Traité de Droit Commercial.

LYON-CAEN e RENAULT - Manuel de Droit Comercial.

MADRID (ALFONSO) - Derecho Laboral Español.

MENDONCA (J. X. CARVALHO DE) - Tratado de Direito Comercial Brasileiro.

MORIN (GASTON) - La revolte du droit contre le code.

PARDESSUS - Cours de Droit Commercial.

polo (ANTONIO) - Del contrato a la relación de trabajo.

PU⿴囗十 1936

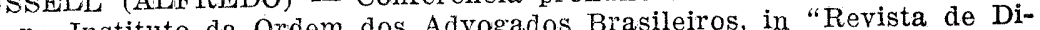
no Instituto da Ordem reito Comercial", vol. 7 .

RUSSEL (ALFREDO) - O Direito Comercial e sua codificação, in Livro do Centenário dos Cursos Jurídicos.

SAYATIER (R.) - Les Métamorphoses Economiques et Sociales du Droit Civil d'aujourd'hui.

SCELLE (GEORGE) - Précis de Legislation Industrielle.

SCELLE (GEORGE) - Le Droit Ouvrier.

THALLER - Traité Elementaire de Droit Commercial.

TRIPOLI (CESAR) - História do Direito Brasileiro. 


\section{RELATÓRIO E PARECER}

\section{Relator: DARIO BITTENCOURT}

A FACULDADE DE DIREITO DO CEARÁ, independentemente de se fazer representar nas comemoracões do cinqüentenário da fundação de sua co-irmã da capital do Estado do Rio Grande do Sul, por intermédio de brilhantíssima delegação de Professores, incumbiu a êsses mesmos Professores de elaborarem interessantes contribuições, as quais, ainda, fêz imprimir em letra de fôrma.

Entre essas contribuições impressas, destaca-se o trabalho de referência acima, de autoria do conhecido intelectual, economista e professor de Direito, Doutor ADERBAL FREIRE - nome merecidamente conhecido em nosso país e, mesmo, no exterior, nos meios que se preocupam mais com as cousas da Economia Política e do Direito do Trabalho.

Em sua bibliografia, entre outros trabalhos, não se poderão olvidar a notável dissertação apresentada, em 1937, à douta congregação da Faculdade de Direito do Ceará e com que conquistou, com raro brilhantismo, a cátedra de "Direito Industrial e Legislação do Trabalho", subordinada à epígrafe - "Direito ao descanso" (Fortaleza, Tip. Minerva - Assis Bezerra, 1937, 182 págs.), assim como "Ensaio de uma sintese do Direito Trabalhista" (Tip. Minerva-Assis Bezerra, Fortaleza, 1938, 96 págs.): trata-se de uma originalíssima contribuição e que só não teve maior ressonância devido ao fato de ter sido elaborada em idioma português; o fôsse, por exemplo, em francês ou inglês - e o renome de seu autor estaria citado nos livros de tomo da especialidade... Não fôsse nossa língua materna "a um tempópo, esplendor e sepultura..."

O Doutor ADERBAL FREIRE traz, agora, para o Congresso Jurídico, um belo estudo, em que busca justificar as razões que militaram a prol da inserção de normas de Direito do Trabalho no centenário Código Comercial de 1850 e, acertadamente, alça a bandeira da inadmissibilidade de sua inclusão, agora, no futuro Código Comercial Brasileiro. Em 40 páginas impressas, o autor do trabalho, de maneira erudita e demonstrando estar perfeitamente em dia com os modernos mestres da disciplina, em estilo atraente, sustenta seu ponto de vista. Em sete capítulos, discorre proficientemente sôbre o assunto que escolheu para opulentar os Anais do presente Congresso, destacando-se o III. ${ }^{\circ}$ subordinado ao título - "Avanços sociais dos Códigos mercantis da Espanha, Portugal e Brasil", no século passado, no qual investiga, em discrime, a questão da natureza jurídica da relação do trabalho, as garantias do direito ao emprêgo, proteção do empregado nos infortúnios imprevistos e inculpados, ressarcimento dos danos extraordinários, a irrenunciabilidade dos diais do primeiro quartel do comprovar que os vetustos códigos comerciatutos que, ainda hoje, século 19 davam foros de cidadania a institutos que, ainda hoje tén modernos repositórios, nacionais e estrangeiros, do Direito do Trabalho.

rafia, brasileira e peregrina, enriquece o traba-

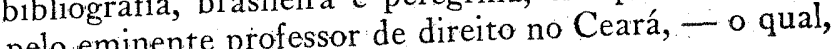
tho apresentado pelo eminente prof

finalmente, oferece as seguintes
CONCLUS Õ E S

- que, de conformidade com a norma do art. 9 do "Regimento InCongresso, inteiramente adotamos, a fim de servirem de base à discussão e votação:

I - A penetrante agudeza com que agiu o legislàdor I - A pene inserindo tais normas no corpo do brasileiro de 1850, inserindo tais normas nalidade elevada digo Comercial, serve de índice da menta relação ao resque presidiu à sua elaboração, m

tante daquela obra legislativa. mesmo, louvável a in-

II - Embora explicável e, mesmo, louvável a intenção do legislador de cem anos atras, em incluir, no contexto do Código, alguns princípios de natureza socontexto essa inclusão não seria admissivel, cial, hodiernamente essa Direito do porque contraria à reconhecida acsiamente, pertencem.

Sala Sesões do CONGRESSO JURÍDICO, na Faculdade de Salo Direito ade Plogre, aos 11 de agôsto de 1950

\author{
Dario de Bittencourt - relator \\ Magdaleno Girão Barroso \\ Henrique Stodieck \\ Mário Seixas Aurvalle \\ Buys de Barros
}

\section{DEBATES EM PLENÁRIO}

SR. PRESIDENTE: - Darcy Azambuja - substituindo ocasionalmente o sr. José Salgado Martins.

Passaremos aro à leitura e exposicão do parecer da Comissão

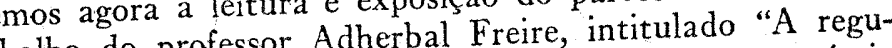
sôbre o trabalho do professor Adrabalho dos empregados do comércio lamentação dos contratos 
E' relator da matéria o professor Dario Bittencourt, a quem concedo a palavra.

O SR. DARIO BITTENCOUR'T - (LE o Relatório e Parecer)

$O$ parecer que acabamos de ler, submetido à apreciação da nona Comissão foi integralmente subscrito.

O SR. PRESIDENTE - Em discussão as conclusões apresentadas pelo relator da Comissão.

O SR. GIRÃO BARROSO - Peço a palavra, Sr. Presidente.

O SR. PRESIDENTE - Tem a palavra o nobre Congressista.

O SR. GIRÃO BARROSO - O dr. Adherbal Freire é nosso colega de trabalho da Faculdade do Ceará e não pôde comparecer a êste Congresso para fazer pessoalmente a defesa de sua tese, em virtude de ter sido designado para acompanhar a nossa embaixada de acadêmicos à Europa. Incumbiu-me, entretanto, de ser também aqui o procurador de ausentes, de fazer a defesa do seu brilhante trabalho, tarefa que, entretanto, me dispenso de fazer, em vista do relatório do parecer muito bem elaborado pelo meu prezado colega Dario Bittencourt.

O SR. PRESIDENTE - Continuam em discussão as conclusões do relator.

Ninguém mais querendo fazer uso da palavra, está em votação. Os srs. Congressistas que não estiverem de acôrdo tenham a bondade de levantar-se. (Pausa).

Aprovado.

\section{INDICAÇÕES SÔBRE DIREITO TRABALHISTA}

\section{Félix Manuel Woelflin $e$ Alfredo J. Ruprecht}

Professôres catedráticos da Universidade de Rosário - República Argentina.

\section{POR CUANTO:}

- Dentro del Derecho Laboral no existe un sólo contrato, sino cantidad de ellos, con naturaleza propia y distinta, tales entre otros, los de "empleo privado", de "empleo público", de "aprendizaje". de "trabajo autónomo", etc.

- Unificar a contratos tan distintos dentro de una denominación única, no tendría razón de ser, y traería consigo funciones que es conveniente evitar.

- El llamado "contrato de trabajo", tiene su significado en la história del Derecho, pero carece de él en la actualidad, al mismo tihabstituto de la "locación de serviços", por el significado contrario a la dignidad humana que a esta última denominación se le atribuía, pedignidad humana que a esta ulima denomina carácter civil.

o su sustractum es el mismo y su origen debe ser precisa y no corresponder a mas de una institución.

POR ELIO EL CONGRESO JURIDICO CONMEMORATIVO DEL CINCUENTENARIO DE LA FUNDACION DE LA FACULTAD DE DERECHO DE RIO GRANDE. DEL SUD DECLARA:

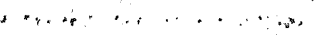

Oue la denominación "contrato de trabajo". és incorrecta, debiendo utilizarse la de "contratos laborales", cuando se refiere a los endo en in sentido amplio ó coneral $y$ la de "contrato" seguido con su denominación específica "de empleo privado", "de empleo público", "de trabajo autónomo", etc.), cuando se refiere a cada uno de ellos en particular. 